\title{
KERJASAMA ANTARDAERAH DALAM PENGELOLAAN MATA AIR UMBULAN WINONGAN PASURUAN PROVINSI JAWA TIMUR
}

\section{INTERREGIONAL PARTNERSHIP IN THE MANAGEMENT OF UMBULAN SPRING WINONGAN PASURUAN EAST JAVA}

\author{
Irtanto $^{1}$ dan Hari Wahyudi ${ }^{2}$ \\ ${ }^{1}$ Badan Penelitian dan Pengembangan Provinsi Jawa Timur \\ ${ }^{1}$ Telp. 031-8290719, e-mail: irtanto@ rocketmail.com \\ ${ }^{2}$ Badan Pendidikan dan Pelatihan Provinsi Jawa Timur \\ ${ }^{2}$ Telp. 031-7412278,e-mail: hary_wahyudi2003@yahoo.com \\ Diterima: 9 Mei 2012, Direvisi: 24 Mei 2012, Disetujui: 31 Mei 2012
}

\begin{abstract}
Abstrak
Tujuan penelitian ini adalah untuk mengidentifikasi produk kebijakan teknis kerjasama untuk implementasi antara Pemerintah Provinsi Jawa Timur, Kabupaten Pasuruan, Kabupaten Sidoarjo, Kabupaten Gresik dan Kota Surabay, serta mengidentifikasi implementasi kerjasama dan kendala yang dihadapi. Pendekatan yang digunakan adalah deskriptif kualitatif. Hasil penelitian menunjukkan bahwa kerjasama pengelolaan mata air Umbulan belum berjalan dengan baik, yang disebabkan oleh belum terbentuknya lembaga kerjasama yang melibatkan kalangan independen dan professional untuk bekerja secara aktif dan intensif; belum adanya payung politik yang memadai; dan kurang pelibatan stakeholders.
\end{abstract}

Kata Kunci: kerjasama antardaerah, implementasi kebijakan, mata air.

\begin{abstract}
The purpose of this study was to identify the products of technical cooperation for the implementation of the policy of the Government of East Java, Pasuruan, Sidoarjo, Gresik and Surabaya, and to identify the implementation of cooperation and constraints. The approach used is descriptive qualitative. The results showed that the joint management of the springs Umbulan not run well, which is caused by the institutions have been formed involving cooperation among independent and professional to work actively and intensively; absence of adequate political umbrella, and lack of involvement of stakeholders.
\end{abstract}

Keywords: interregional cooperation, policy implementation, springs.

\section{PENDAHULUAN}

Kerjasama antardaerah telah digulirkan oleh pemerintah sejak pasca orde baru, yang diformalkan di dalam Undang-UndangNomor 32 Tahun 2004 tentang Pemerintahan Daerah, yang menyebutkan bahwa pelaksanaan urusan pemerintahan yang mengakibatkan dampak lintas daerah dikelola bersama oleh daerah terkait, dan untuk menciptakan efisiensi, daerah wajib mengelola pelayanan publik secara bersama dengan daerah sekitarnya untuk kepentingan masyarakat. Demikian pula regulasi lainnya terkait dengan pemanfaatan sumber daya air melalui Undang-Undang Nomor 7 Tahun 2004 tentang Sumber Daya Air, yang mengamanatkan bahwa pengelolaan sumber daya air berasaskan kelestarian, keseimbangan, kemanfaatan umum, keterpaduan, dan keserasian, keadilan, kemandirian serta transparansi dan akuntabilitas. Selanjutnya, Undang-Undang Nomor 7 Tahun 2004 menyebutkan tersebut mengamanatkan bahwa sumber daya air dikuasai oleh negara dan dipergunakan untuk sebesar-besar kemakmuran rakyat. Makna penguasaan sumber daya air artinya bahwa penye- lenggaraannya dilakukan oleh pemerintah atau pemerintah daerah, serta tidak bertentangan dengan kepentingan nasional. Atas dasar itulah, maka ditentukan hak guna air. Secara spesifik, menurut Undang-Undang Nomor 7 Tahun 2004 bahwa sumber daya air dikelola secara menyeluruh, terpadu dan berwawasan lingkungan hidup, dengan tujuan mewujudkan pemanfaatan sumber daya air yang berkelanjutan untuk sebesar-besarnya kemakmuran rakyat.

Dari aspek regulasi, yang tidak penting adalah regulasi pengaturan kewenangan dalam kerjasama antardaerah dalam pengelolaan air yang telah diatur melalui Peraturan Pemerintah Nomor 25 Tahun 2000, yang menyatakan bahwa kewenangan pemerintah provinsi adalah dalam hal penetapan standar pengelolaan sumber daya air permukaan yang bersifat lintas kabupaten/kota, serta pengaturan tentang pengamanan dan pelestarian sumber daya air lintas kabupaten/kota. Adapun kewenangan pemerintah kabupaten/kota, yaitu dalam penetapan persyaratan, pengaturan, mekanisme dan pelaksanaan pemberian ijin serta pengelolaan atau 
pemanfaatan air/mata air yang ada di dalam wilayah kabupaten/kota tersebut.

Bila dikaitkan dengan kebutuhan masyarakat akan air bersih yang semakin meningkat, maka berbagai regulasi tersebut di atas nampaknya relevan dengan permasalahan di Kota Surabaya, Kabupaten Pasuruan, Kabupaten Sidoarjo dan Kabupaten Gresik yang penduduknya semakin meningkat jumlahnya, yang kesemuanya membutuhkan pasokan air bersih yang cukup. Namun di sisi lain, terdapat keterbatasan jumlah debit air bersih yang disediakan oleh PDAM masingmasing daerah tersebut, yang diperoleh dari mata air Umbulan di Kabupaten Pasuruan yang memiliki 9 titik mata air dan memiliki debit rata-rata 5000 liter/detik, dimana terletak sekitar $13 \mathrm{~km}$ dari lereng kaki Gunung Bromo, Semeru dan berada $27 \mathrm{~m}$ di atas permukaan laut.

Pemanfaatan mata air Umbulan dipandang sebagai kegiatan strategis oleh Pemerintah Provinsi Jawa Timur. Karena itu, Pemerintah Provinsi menginisiasi lahirnya kerjasama antardaerah yang tertuang dalam kesepakatan Nomor 120.1/81/012/2004 tentang Kerjasama Pengelolaan Sumber Daya Air Umbulan di Kabupaten Pasuruan. Namun dalam implementasinya, kerjasama tersebut belum optimal untuk memenuhi kebutuhan keempat daerah tersebut.

Oleh karena itu, perlu dilakukan penelitian mengenai kerjasama antardaerah dalam pengelolaan dan pemanfaatan mata air Umbulan tersebut, agar dapat diidentifikasi produk-produk kebijakan teknis operasional yang sudah dilakukan oleh masingmasing pemerintah daerah yang bekerjasama, yang selanjutnya dapat diidentifikasi permasalahan yang ada dalam implementasi kerjasama tersebut, dan apa upaya-upaya mengatasinya.

Cooper (dalam Solichin AW. dkk, 2002) membuat ciri-ciri kerjasama antar Pemerintah Daerah, sebagai "They are generally agreement between two goverment concerning single activity. They pertain to service rather than to facilities. They are not permanent and contains provision for future renegotiating or termination by either party. They have stand-by provisions that come into neffleck only when certain conditions arise; and they permitted by state legislation that authorizes cooperation among local government in specific areas". Artinya bahwa kerjasama antarpemerintah akan memudahkan kedua belah pihak dan dapat dilakukan sewaktu-waktu, atau tidak permanen.

Yuwono (2004) mengungkapkan bahwa kerjasama pada umumnya meliputi beberapa elemen pokok yang bisa meliputi dua konsep utama, yaitu kerjasama antar sektor dan kerjasama antar aktor dalam sebuah ruang lingkup yang jelas. Hal tersebut lebih ditekankan oleh Dallery (2000), bahwa kerjasama antar sektor dalam perspektif manajemen publik sebagai sesuatu yang penting, karena menyangkut perlunya penanganan sebuah kegiatan atau program publik yang berorientasi pada kesejahteraan umum. Egoisme sektoral yang selama ini dipandang sebagai hal yang menyebabkan kegagalan pembangunan, disebabkan oleh integrasi dan kemitraan pelaksanaan pembangunan tidak dapat terlaksana dengan baik. Adapun kerjasama antaraktor merupakan bagian yang tidak kalah pentingnya, karena faktor ini sangat menentukan sejauhmana program kerjasama dapat dilakukan dengan baik. Keterlibatan aktor, baik yang berada di sektor publik, privat maupun masyarakat, menentukan skala kemitraan dan efektivitasnya dapat terjaga. Kemitraan untuk melakukan kerjasama dan kesediaan untuk mengadakan kerjasama merupakan aspek pokok yang menentukan efektivitas dan efisiensi kerjasama tersebut. Makna yang lebih luas dari itu adalah bahwa kerjasama tersebut dibangun dari suatu kebijakan yang terkait dengan masyarakat

Etzioni (1967), menyatakan bahwa kinerja implementasi kebijakan akan dipengaruhi oleh kebijakan publik; organisasi dan strategi implementasi; dan kondisi lingkungan. Dalam praktiknya, ketiga variabel tersebut saling mempengaruhi satu dengan yang lain. Konsep ini memiliki pola kesamaan dengan pemikiran Dye (1978), bahwa di dalam sistem kebijakan, yang digambarkan ke dalam tiga elemen yang saling mempengaruhi, yakni kebijakan publik, pelaku kebijakan, dan lingkungan kebijakan.

Sejalan dengan implementasi kerjasama Etzioni melahirkan konsep tentang ketiga faktor yang mempengaruhi kinerja implementasi kebijakan publik dapat digambarkan sebagai berikut, yakni: Pertama, kebijakan publik yang dimaksud merupakan bentuk kebijakan apa yang hendak diterapkan pengambil keputusan kepada masyarakat penerima kebijakan. Kedua, organisasi dan strategi implementasi, ini berhubungan dengan keterlibatan lembaga-lembaga terkait pelaksanaan kebijakan, berikut strategi apa yang hendak dilaksanakan dan dikembangkan sehubungan dengan bentuk kebijakan yang telah diputuskan. Ketiga, kondisi lingkungan berkaitan dengan dukungan yang diberikan masyarakat yang terkena kebijakan maupun dukungan dari organisasi internal pemerintah yang terkait dengan pelaksanaan kebijakan. Analogi terhadap konsep Etzioni tersebut, dapat dijelaskan pada kasus pengelolaan mata air Umbulan, di mana bentuk sifat urgensi kebijakan yang diambil pemerintah, apakah mendapat dukungan atau tentangan dari lingkungan masyarakat sehubungan dengan eksternalitas positif maupun negatif yang mungkin akan dialami lingkungan masyarakat penerima bentuk kebijakan; karena sebuah kebijakan berkaitan dengan tanggung jawab yang dilaksanakan antar lembaga, maka kapasitas atau kemampuan dalam bentuk performance lembaga publik beserta aparatnya, disertai kemampuan dalam menyusun dan melaksanakan strategi akan mempengaruhi kinerja implementasi kebijakan publik. Relevansi konsep 
Etzioni diperkuat dengan pendapat Dye, bahwa suatu proses kebijakan terbentuk melalui elemen-elemen sistem kebijakan atau pola institusional melalui di mana kebijakan tersebut dibuat dan memiliki hubungan timbal balik, yaitu antara pelaku kebijakan, kebijakan publik dan lingkungan kebijakan.

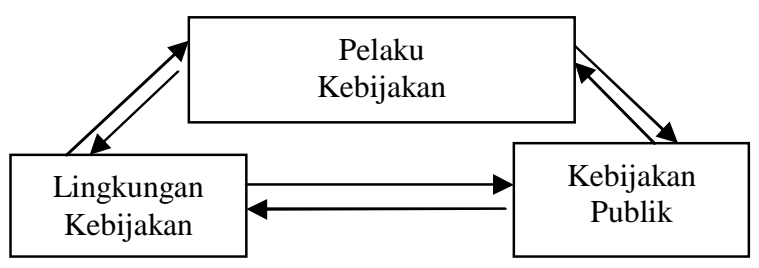

Sumber: Dye, 1978.

\section{Gambar 1. Tiga Elemen Sistem Kebijakan.}

Untuk memahami proses implementasi kebijakan dalam pengelolaan mata air Umbulan, dapat dipergunakan model proses implementasi kebijakan berdasarkan rumusan Van Meter, yang dapat diketahui dari sejumlah variabel, yaitu: komunikasi antar organisasi dan kegiatan pelaksanaan; ukuran dan tujuan kebijakan; sumbersumber kebijakan; karakteristik badan pelaksana; sikap para pelaksana; dan lingkungan ekonomi, sosial, politik.

Selanjutnya, proses implementasi kebijakan ini akan mengalami keberhasilan, tergantung pada derajat perubahan, kontrol dan kepatuhan dalam melaksanakan prosedur implementasi kebijakan. Intinya bahwa proses implementasi kebijakan akan berhasil apabila perubahan yang dikehendaki relatif sedikit, sementara kepatuhan bertindak terhadap kesepakatan tujuan serta kontrol yang dijalankan, terutama dari mereka yang mengoperasikan program di lapangan relatif tinggi (Wahab, 1997). Mempertimbangkan kedua pendapat tersebut, maka dalam proses implementasi kebijakan, yang melibatkan berbagai tingkat lembaga atau organisasi antar pemerintah dapat dilakukan modifikasi adopsi pendapat Goggin (1990). Dalam model komunikasi antar organisasi pemerintah, digambarkan terdapat hubungan yang mempengaruhi hasil implementasi kebijakan. Pemerintah pada level provinsi dapat mempengaruhi hasil-hasil kebijakan pemerintah daerah dalam bentuk kebijakan yang mendorong maupun menghambat implementasi kebijakan. Sedangkan hasil-hasil kebijakan daerah ini juga ditentukan oleh masing-masing kapasitas daerah, selanjutnya secara bersamaan akan mempengaruhi implementasi kebijakan.

Fokus utama studi implementasi adalah persoalan bagaimana organisasi berperilaku, atau bagaimana orang berperilaku dalam organisasi. Akan tetapi, jika kita menerima bahwa implementasi adalah sebuah proses yang melibatkan "jaringan" organisasi, pertanyaannya adalah bagaimana organisasi berinteraksi satu sama lain. Ada dua pendekatan yang muncul dalam persoalan ini. Pendekatan kekuasaan dan ketergantungan sumber daya. Pendekatan ini berargumen bahwa interaksi organisasi adalah produk dari hubungan kekuasaan di mana organisasi-organisasi dapat membuat organisasi yang lebih lemah dan lebih tergantung untuk berinteraksi dengan mereka. Pada gilirannya, organisasi-organisasi yang tergantung pada organisasi-organisasi yang lebih kuat harus menjalankan strategi bekerja sama dengan organisasi yang kuat untuk mengamankan kepentingan mereka dan mempertahankan otonomi relatifnya atau mempertahankan ruang mereka untuk beroperasi (Aldrich, diadopsi oleh Persons, 2005). Pendekatan pertukaran organisasional. Pendekatan ini menyatakan bahwa organisasi bekerja dengan organisasi lain dengan saling mempertukarkan manfaat mutual. Ciri utama dari pertukaran antarorganisasi adalah pertukaran itu merupakan interaksi sukarela yang dilakukan demi mencapai tujuan masing-masing pihak (Levine dan White, 1961, dalam Parsons, 2005). Dalam model ketergantungankekuasaan, relasi organisasional didasarkan pada dominasi dan dependensi, sedangkan pertukaran didasarkan pada kepentingan bersama (Bish, Tite, White, dalam Persons, 2005).

\section{METODE PENELITIAN}

Penelitian ini dilakukan di Kabupaten Pasuruan, Kabupaten Sidoarjo, Kabupaten Gresik dan Kota Surabaya. Pendekatan yang digunakan adalah deskriptif kualitatif, dengan menggunakan metode studi kasus untuk mengungkap bagaimana realitas implementasi kerjasama pengelolaan mata air Umbulan. Ruang lingkup penelitian ini difokuskan pada masalah-masalah kebijakan teknis apa yang ditempuh selama ini dan kendala-kendala yang terjadi selama implementasi kebijakan dan program kerjasama pengelolaan mata air Umbulan Kabupaten Pasuruan. Secara teknis hal ini lebih menekankan pada deskripsi ex post facto tentang aktivitas program yang sedang berjalan, yang selanjutnya berhubungan dengan output dan impact dari implementasi kebijakan kerjasama pengelolaan mata air Umbulan.

Teknik pengumpulan data yang dilakukan melalui studi dokumen, program, wawancana mendalam (indepth interview) dengan pembuat kebijakan dan administrator seperti Sekretaris Daerah, DPRD, PDAM, Bappekab, dan Pengawas PDAM dengan teknik snowball untuk mengidentifikasi, mendefinisikan dan menspesifikasikan tujuan dan target kebijakan. Kemudian teknik focus group discussion (FGD) yang melibatkan para pembuat kebijakan dan administrator serta pihak-pihak terkait. FGD kami gunakan untuk melengkapi data yang telah diperoleh 
untuk melihat permasalahan-permasalahan yang berkembang.

Selanjutnya data dan informasi yang telah terkumpul dianalisis dengan menggunakan metode ex post facto. Dari hal tersebut yang kemudian diinterpretasikan berdasarkan pengelompokkan orientasi masalah dan kendala-kendala atas aspekaspek internal dan eksternal yang mendukung serta menghambat implementasi kerjasama pengelolaan mata air Umbulan di Kabupaten Pasuruan.

\section{HASIL DAN PEMBAHASAN}

\section{Deskripsi Lokasi Penelitian}

Di wilayah Kabupaten Pasuruan terdapat enam mata air, yaitu Umbulan, Banyubiru, Semut, Kaliadem, Watugajah, Mego, dan Trobayan. Mata air Trobayan kondisinya masih alami, air keluar dari celah batu gunung (stone belt), debetnya diperkirakan $0,3 \mathrm{~m}^{3} /$ detik dimanfaatkan untuk irigasi dan suplai Sungai Rekoso. Untuk menjangkaunya, harus ditempuh berjalan kaki sekitar $1 \mathrm{~km}$ dari jalan beraspal, terletak di Kecamatan Winongan. Adapun mata air Banyubiru telah dibangun dan dikelola untuk kepentingan masyarakat, yang debetnya diperkirakan $0,5 \mathrm{~m}^{3} /$ detik dan telah dimanfaatkan untuk kepentingan PDAM Grati, kolam renang, irigasi (Prodo dan Bantaran) dan suplai Sungai Rekoso sebanyak 340 lt/det. Lokasi mata air Banyubiru terletak di Kecamatan Winongan. Kemudian, mata air Semut kondisinya masih alami, yaitu berupa kolam penampung berbentuk bulat dengan diameter \pm 15 meter yang disekelilingnya berupa tanaman "bulung" (pepohonan Sagu). Mata air Semut belum memiliki bangunan, dengan ukuran debet airnya diperkirakan mencapai $0,4 \mathrm{~m}^{3} /$ detik yang dipergunakan untuk mengairi sawah dan untuk suplai Sungai Rekoso.

Selanjutnya, mata air Kaliadem, yang lokasinya terletak di Kecamatan Winongan, yang kondisinya masih alami, terdiri dari mata air kecilkecil yang tersebar kemudian mengumpul pada satu saluran outlet, terletak di sela tanaman dan lahan persawahan dengan debet diperkirakan $0,5 \mathrm{~m}^{3} /$ detik, dimanfaatkan untuk irigasi dan suplai Sungai Rekoso. Mata air Watugajah telah dibangun kolam penampungan dengan luas \pm 13 × 35 meter, belum dikelola dengan baik. Mata air Watugajah belum ada bangunan ukur debit, debitnya diperkirakan 0,1 $\mathrm{m}^{3}$ /detik dan dimanfaatkan untuk irigasi saja. Lokasi mata air Watugajah juga terletak di Kecamatan Winongan. Kemudian, mata air Mego kondisinya masih alami berupa kolam dangkal dan ditumbuhi tanamanan air, terletak di antara lahan tebu. Mata air Mego debitnya diperkirakan $0,2 \mathrm{~m}^{3} /$ detik yang dimanfaatkan untuk irigasi dan suplai ke Sungai Rejoso dan berlokasi di Kecamatan Winongan.

Mata air Umbulan yang akan dikerjasamakan antara Pemerintah Provinsi Jawa Timur dengan Kabupaten Pasuruan, Sidoarjo, Gresik dan
Kota Surabaya juga terletak di Kecamatan Winongan. Mata air Umbulan yang akan dijadikan bahan baku air minum sebagian telah dikelola untuk kepentingan masyarakat. Pengelolaan ataupun pemanfaatan mata air Umbulan sangat prospektif untuk dikerjasamakan. Hal ini mengingat debit airnya sangat besar, yakni mencapai 5.500 liter/detik, dan tidak lebih dari 500 liter/detik yang telah dimanfaatkan untuk kepentingan masyarakat. Menurut data Dinas Permukiman Provinsi Jawa Timur, mata air Umbulan saat selama ini telah dimanfaatkan untuk kepentingan PDAM Kota Surabaya sebanyak 110 lt/detik, PDAM Kabupaten Pasuruan sebanyak 165 lt/det, irigasi dan kolam ikan sebanyak 500 lt/det, sedangkan sisanya sekitar 4.000 liter/detik dibiarkan mengalir ke sungai dan areal persawahan, dan selain itu dimanfaatkan pula untuk suplai Sungai Rejoso.

Kondisi di atas tentu sangat ironis dengan kebutuhan air bersih bagi masyarakat perkotaan yang terus meningkat jumlah penduduknya. Jika proyek kerjasama pengelolaan mata air Umbulan ini terlaksana, tidak hanya masyarakat Kabupaten Pasuruan saja yang dapat menikmatinya, masyarakat Kabupaten Sidoarjo, Kabupaten Gresik dan Kota Surabaya tentu bisa menikmatinya juga. Debet mata air Umbulan akan dimanfaatkan sebesar 3.200 lt/detik, di mana untuk melayani Kota Surabaya bagian Timur-Utara sebanyak 1.000 lt/detik, Kabupaten Sidoarjo (Kota, Waru \& Porong) sebanyak 2.000 1t/det dan Kabupaten Pasuruan terutama PIER sebanyak 200 lt/det. Apapun menurut Greater Surabaya yang diadopsi oleh Dinas Permukiman Provinsi Jawa Timur, debet mata air Umbulan dimanfaatkan sebesar 3.200 lt/det, di mana untuk melayani Kabupaten Gresik sebanyak 1.000 lt/det, Kabupaten Sidoarjo sebanyak 1.750 lt/det dan Kabupaten Pasuruan sebanyak 400 lt/det. Sedangkan Bank Dunia menilai bahwa suplai mata air Umbulan dapat dipergunakan untuk Kabupaten Pasuruan sebanyak 400 lt/det, Kabupaten Sidoarjo sebanyak $1.600 \mathrm{lt} / \mathrm{det}$, Kota Surabaya sebanyak $1.000 \mathrm{lt} / \mathrm{det}$, dan Kabupaten Gresik sebanyak 1.000 lt/det.

Potensi mata air Umbulan sudah dikenal hingga ke mancanegara, di mana beberapa pengusaha nasional ingin mengelola mata air yang berkapasitas 5.500 liter/detik tersebut, bahkan Bank Dunia juga terpikat untuk mendanai proyek tersebut. Pemerintah Kabupaten Pasuruan sendiri pula mempunyai alasan yang kuat untuk segera membangun jaringan transmisi pipa besar dari Umbulan hingga Gempol. Selain untuk memenuhi kebutuhan masyarakat dengan kapasitas sekitar 450 liter/detik, aliran air ini akan dimanfaatkan ratusan perusahaan yang sampai saat ini masih memanfaatkan air bawah tanah (ABT). Malahan PT. Cheil Jedang Indonesia (CJI) sudah memesan sebesar 250 liter/detik, dan menyatakan kesanggupannya untuk sharing investasi pembuatan jaringan transmisi pipa besar. Jumlah perusahaan yang akan 
memakai mata air tersebut bakal bertambah lagi, karena masih banyak perusahaan berskala besar yang berada dikawasan PIER hingga Gempol. Dampak positif jika jaringan transmisi pipa besar ini sudah dibangun, akan mengurangi pemanfaatan ABT oleh berbagai perusahaan yang ada di wilayah Kabupaten Pasuruan, karena perusahaan diwajibkan memanfaatkan saluran air PDAM. Dengan demikian, potensi pemanfatan ABT akan terkurangi. Meski membangun transmisi pipa sendiri, Pemerintah Kabupaten Pasuruan akan tetap memfasilitasi beberapa wilayah lain, seperti Kabupaten Sidoarjo, Kota Surabaya dan Kabupaten Gresik untuk memanfaatkan mata air Umbulan. Hanya saja, mereka harus menyambung sendiri jaringan transmisi pipa besar dari Gempol.

Terlepas dari fakta di atas, nampaknya prosentase bagi hasil proyek air Umbulan akan menjadi masalah tersendiri dalam kerjasama, di mana masing-masing pihak kemungkinan akan mempertahankan posisinya, terutama oleh pemilik mata air tersebut. Hal ini menyangkut berapa rupiah yang akan masuk ke kas daerah untuk konstribusi bagi pendapatan asli daerah (PAD). Namun, alangkah ironisnya jika alasan bagi hasil itu yang semata-mata dijadikan dasar molornya dan tidak jelasnya pelaksanaan proyek mata air Umbulan.

\section{Produk Kebijakan Teknis Operasional}

Pemerintah Provinsi Jawa Timur dan Pemerintah Kabupaten Pasuruan telah menandatangani MoU Nomor 120.1/81/012/2004 tentang kerjasama Pengelolaan Sumber Daya Air Umbulan di Kabupaten Pasuruan. MoU tersebut kemudian ditindak lanjuti dengan Keputusan Bersama Gubernur Jawa Timur dan Bupati Pasuruan nomor 188/186/KPTS/013/2005 dan nomor 180/07/HK/ 424.022/2005 tentang Tim Kerjasama Pengelolaan Mata air Umbulan di Kabupaten Pasuruan. Kedua kesepakatan itu ditindaklanjuti dengan Keputusan Ketua Tim Kerjasama Pengelolaan Mata air Umbulan di Kabupaten Pasuruan nomor 539/315.1/ KPTS/021/2006 tentang Kelompok Kerja Pengelolaan Mata Air Umbulan di Kabupaten Pasuruan. Tim tersebut terdiri dari para pejabat di lingkungan instansi Pemerintah Provinsi Jawa Timur dan Pemerintah Kabupaten Pasuruan.

Lahirnya keputusan bersama antara Gubernur Jawa Timur dengan Bupati Pasuruan tersebut di atas, merupakan bentuk kebijakan yang dilakukan diluar etika hubungan komunikasi antar tingkat birokrasi yang biasanya dipahami selama ini dalam konsep hirarkhi birokrasi, yang menempatkan tingkatan pola hubungan hirarkhi kewenangan antara atasan dan bawahan bukanlah bersifat hubungan komunikasi yang bersifat sejajar. Penerapan prinsip "primus interpares" di dalam pembuatan keputusan bersama yang dilakukan Gubernur Jawa Timur dengan Bupati Pasuruan, merupakan kebijakan yang tidak bertentangan dengan aturan penyelenggaraan pemerintahan berdasarkan Undang-Undang Nomor 32 Tahun 2004 tentang Pemerintahan Daerah, akan tetapi dari sisi kepatutan etika administrasi publik, suatu bentuk kerjasama antar pemerintahan daerah akan dilakukan dalam satu level pemerintahan daerah. Hal ini berarti, bahwa pemerintahan provinsi di dalam melakukan hubungan komunikasi kebijakan dengan pemerintah kabupaten/kota lebih berada pada posisi yang melakukan "penawaran kerjasama" dibandingkan sebagai "fasilitator".

Pada sisi lain, di dalam proses kebijakan pengelolaan mata air Umbulan dibentuk, tidak melibatkan sepenuhnya elemen-elemen seperti pelaku kebijakan maupun lingkungan kebijakan, yaitu masyarakat, privat/pelaku profesional seperti yang dikonsepkan Dye (1975) dan hal ini sejalan dengan konsep good governance, bahwa untuk mewujudkan pemerintahan yang baik antara lain harus melibatkan privat dan masyarakat. Oleh karenanya, dari sisi proses kebijakan pengelolaan mata air Umbulan tersebut dipandang masih banyak kelemahannya.

\section{Upaya untuk Mengimplementasikan Kerjasama}

Megaproyek pengelolaan mata air Umbulan menurut rencana menghabiskan dana sekitar sebesar Rp 1,2 triliun. Dana sebesar itu diperuntukan bagi pembangunan infrastruktur sebesar $\mathrm{Rp} 900$ miliar dan untuk pipa distribusi sepanjang $63 \mathrm{~km}$ sebesar Rp 300 miliar. Harapannya, pada tahap awal Bank Dunia mengadakan studi lebih dahulu dan kemungkinan akan memberikan pendanaan untuk jalur distribusinya, sedangkan proyek Umbulannya diharapkan bisa dikerjakan BUMD Jawa Timur, namun tetap dengan proses tender. Ketertarikan Bank Dunia, disebabkan mata air Umbulan memiliki potensi besar untuk memenuhi kebutuhan air di Kabupaten Pasuruan, Kabupaten Sidoarjo, Kabupaten Gresik, dan Kota Surabaya. Daerahdaerah tersebut sangat mungkin akan mengalami kekurangan air bersih. Karena itu, Bank Dunia berusaha keras untuk berinvestasi di proyek Umbulan. Mata air Umbulan merupakan prioritas yang akan dikerjakan PDAB (Perusahaan Daerah Air Bersih) Jawa Timur.

Untuk sharing pendanaan antara Kabupaten Sidoarjo, Kabupaten Pasuruan, Kabupaten Gresik, dan Kota Surabaya yang selama ini menjadi masalah, masih dalam tahap pengkajian. Proyek air bersih Umbulan tetap berjalan, meski tanpa bantuan Bank Dunia, Pemerintah Provinsi mempersiapkan proses tender baru, tender yang lalu telah diputus berdasarkan keputusan pengadilan. Pemerintah Provinsi sedang mengumpulkan data terbaru di antaranya mengenai lokasi strategis yang akan dilewati pipa air. Data lama menunjukkan pipa masih mengikuti alur jalan tol yang terkena lumpur panas Sidoarjo. Pemerintah Provinsi berinisiatif mencari lokasi yang lebih baik dan aman, meskipun rencana tersebut masih berupa wacana, karena membutuhkan 
waktu yang lama. Masalah lainnya, adalah kurangnya pengendalian mata air seperti debit air yang dulunya sebanyak 5,2 ribu liter/detik, tetapi sekarang sudah berkurang menjadi 4 liter/detik. Hal ini dikarenakan banyaknya rumah dan perusahaanperusahaan air minum yang mengebor sumber. Hal lainnya, menyangkut proses tender, di mana saat ini sedang dilakukan persiapan proses dokumen tender yang diperkirakan selesai 2-3 bulan, dan pelaksanaan tender 7-8 bulan. Jika memang investornya memenuhi harapan, maka langsung bisa dikerjakan. Ada dua proyek yang berjalan, yaitu membangun transmisi dan distribusi. Untuk transmisi, dikerjakan investor dan bisa disertai kerjasama dengan pemerintah kabupaten/kota atau provinsi, sedangkan Bank Dunia diberikan kesempatan untuk membantu proyek distribusi.

Selanjutnya untuk mengimplementasi-kan tender investasi pengelolaan mata air Umbulan, telah dibentuk beberapa Kelompok Kerja (Pokja) yang mempunyai tugas menyusun langkah-langkah pelaksanaan proyek Umbulan, di antaranya analisis mengenai dampak lingkungan dan penyelesaian dokumen tender. Selama ini debit air yang ada di empat kabupaten/kota yang akan terlibat proyek, kecil sekali dan tidak menjangkau seluruh masyarakat. Di Kota Surabaya, 60 persen penduduk saja yang bisa di-cover air PDAM, sedangkan Kabupaten Sidoarjo hanya 30 persen. Dengan kapasitas produksi $5 \mathrm{~m}^{3} /$ detik, mata air Umbulan bisa menambah jangkauan air ke masyarakat.

Upaya Pemerintah Provinsi Jawa Timur untuk mewujudkan kerjasama pengelolaan mata air Umbulan, mengalami hambatan berupa tuntutan dari PT. Mandala Citra Umbulan (MCU). Selama ini PT. Mandala Citra Umbulan (MCU) memang mengklaim telah memenangkan gugatan perdata di Mahkamah Agung (MA), namun Pemerintah Provinsi Jawa Timur bergeming. Klaim tersebut tidak menghalangi rencana Pemerintah Provinsi Jawa Timur untuk berencana melaksanakan proyek terebut. Mereka tetap berniat melelang proyek pengelolaan mata air Umbulan. Pemerintah Provinsi melalui PDAB telah menyiapkan dokumen tender untuk melanjutkan proyek pengelolaan mata air Umbulan. BUMD milik Pemerintah Provinsi itu juga telah menyiapkan dana Rp 1,3 trilyun yang diambil dari aset PDAB sendiri. Faktanya, bahwa kelanjutan proyek pengelolaan mata air Umbulan tampaknya masih akan tersendat lagi, karena PT. Mandala Citra Umbulan (PT MCU), perusahaan yang memenangkan tender pengerjaan proyek itu, memenangkan gugatannya di Mahkamah Agung (MA). Gugatan tersebut terkait pemutusan kontrak proyek tersebut secara sepihak oleh Pemerintah Provinsi Jawa Timur. PT. MCU mengatakan bahwa seharusnya sebelum mengambil langkah-langkah dengan menenderkan kepada pihak lain, PDAB harus mengajak PT. MCU berunding, sebab putusan MA memenangkan PT. MCU telah berkekuatan hukum tetap.

\section{Kendala dalam Implementasi Kerjasama}

Beberapa kendala yang bisa menyebabkan beberapa kemungkinan molornya implementasi kerjasama mata air Umbulan, seperti alotnya negosiasi yang memakan waktu yang begitu lama, di mana calon investor menginginkan jaminan. Hal ini harus ada pertanggungjawabannya. Investor kuatir apabila suatu saat air Umbulan mengering, pihak mana yang harus bertanggung jawab, meski dalam hal ini dipastikan merupakan tanggung jawab pemerintah, sedangkan pipa transmisi atau distribusi bisa tanggung jawab investor.

Mengenai negosiasi yang alot pada tahap awal, Pemerintah Kabupaten Pasuruan menawarkan pengelolaan Umbulan dengan Pemerintah Provinsi Jawa Timur sebagai bagi hasil dengan persentase 70:30. Hal ini didasarkan letak mata air Umbulan yang memang berada dalam wilayah Kabupaten Pasuruan. Namun setelah dilakukan perundingan, Pemerintah Kabupaten Pasuruan akhirnya bersedia menurunkan perolehan bagi hasil menjadi 60:40. Tetapi, keputusan itu dirasakan masih belum cukup, di mana Pemerintah Provinsi Jawa Timur tetap bersikukuh dengan persentase 50:50. Ketika penelitian dilaksanakan, kesepakatan bagi hasil masih belum selesai. Belum selasainya perundingan teknis soal bagi hasil ini, tentu saja membuat calon investor lain yang berminat mengelola mata air Umbulan tidak berani melangkah. Padahal sudah banyak investor yang bersedia menanamkan investasi dengan nilai total sekitar Rp 1,4 trilyun. Para investor itu selain konsorsium asal Singapura juga berasal dari Malaysia, Taiwan, Australia dan Jepang.

Pemanfaatan mata air Umbulan dikelola sejak jaman penjajahan Belanda untuk kepentingan Belanda. Era otonomi daerah pengelolaan mata air Umbulan menjadi kewenangan Pemerintah Provinsi Jawa Timur, karena mata air Umbulan melintasi beberapa daerah. Implementasi Mou antara Pemerintah Provinsi Jawa Timur dengan Kabupaten Pasuruan tentang pengelolaan mata air Umbulan, juga menghadapi kendala ketika tim kelompok kerja dan tim teknis adalah para pejabat, sehingga kinerja mereka kurang maksimal dan realitasnya tim yang dibentuk tersebut belum berjalan dengan baik, karena struktur pengambilan keputusan terlalu berjenjang dan sangat gemuk

Selama ini belum terbangunnya kesepakatan antara Pemerintah Provinsi Jawa Timur dengan Pemerintah Kabupaten Pasuruan tentang pembagian hasil. Persoalan kepentingan ekonomi yang dikedepankan, bukan kepentingan lebih luas/bersama, sehingga saling tarik ulur soal pembagian hasil mata air Umbulan, padahal mata air Umbulan mempunyai nilai sosial yang tinggi. Hal ini sebagai salah satu akibat otonomi daerah yang mengakibatkan munculnya egoisme kedaerahan, yang hanya mementingkan daerahnya sendiri tanpa melihat aspek yang lebih luas. 
Selain hal-hal di atas, kendala utama adalah: (1) Dana, di mana investor yang mau mendanai proyek kerjasama tersebut belum jelas. Selama ini pihak Pemerintah Provinsi Jawa Timur maupun Pemerintah Kabupaten Pasuruan berusaha mendatangkan investor, namun belum berhasil; (2) Tim Kerjasama Pengelolaan Mata air Umbulan kurang komitmen terhadap MOU, sehingga hanya terbatas pada kesepahaman saja, tetapi masih belum sampai pada tingkatan kesepakatan; (3) Tim selalu melekat dengan jabatan di birokrasinya. Tidak ada wakil dari kalangan privat, kalangan profesional dan masyarakat. Biasanya pekerjaan dibirokrasinya lebih diprioritaskan daripada pekerjaan lainnya; (4) Tidak ada kelompok kerja sebagai pelaksana. Walaupun tim telah dibentuk sedemikian gemuknya, namun kelompok kerja sebagai pelaksananya belum ada; dan (5) Anggaran yang tidak tersedia untuk tim pengelolaan kerjasama mata air Umbulan, sehingga tim enggan untuk bekerja.

Faktor kelembagaan yang menyebabkan pengelolaan kerjasama tersebut tidak berjalan maksimal, adalah tidak adanya lembaga otonom yang menanganinya, dan selama ini tim yang dibentuk terdiri dari orang-orang birokrat yang melekat pada jabatannya. Senada dengan hal di atas, bahwa persoalan tidak berjalannya kerjasama pengelolaan mata air Umbulan lebih banyak menyangkut persoalan politik, yaitu otonomi daerah yang dimaknai dengan kebebasan daerah untuk perbuat apa saja, sehingga egoisme daerah muncul. Kelemahan lainnya adalah tidak adanya lembaga yang lebih independen yang berwenang mendata dan menginformasikan serta membuat rekomendasi tentang pemanfaatan mata air Umbulan. Dengan demikian, akan selalu ada perbedaan persepsi dan rekomendasi dalam hal pemanfaatan mata air Umbulan.

Proses implementasi kebijakan pengelolaan sumber daya air Umbulan Kabupaten Pasuruan, dapat dipahami dengan mempergunakan model proses implementasi kebijakan berdasarkan rumusan Van Meter, yakni mengapa implementasi kerjasama pengelolaan mata air Umbulan tersebut tidak berjalan efektif dimungkinkan karena minimnya komunikasi antar sesama tim yang bekerjasama, apalagi tim dibentuk dari para birokrat yang kebanyakan menunggu perintah. Selain itu sikap para pelaksana sendiri yang lebih mementingkan kepentingan ekonomi daerah masing-masing yang tidak bergeming pada pendiriannya yang mempersoalkan pembagian hasil. Sebab lain terhambatnya kerjasama adalah faktor politik, yaitu otonomi daerah, yang menyebabkan egoisme daerah yang lebih mementingkan kepentingan daerahnya sendiri daripada kepentingan yang lebih luas. Dengan dalih otonomi daerah, Pemerintah Daerah tidak mau berkoordinasi dengan pihak-pihak lain yang sekiranya tidak menguntungkan daerahnya secara ekonomis. Oleh karenanya, Pemerintah
Provinsi Jawa Timur mengalami kesulitan untuk menggalang kerjasama antardaerah, termasuk pengelolaan mata air Umbulan.

Dari sisi proses kerjasama, terutama perumusan kebijakan nampaknya strategi yang diambil masih mengandung kelemahan, sehingga dalam mengimplementasikan kebijakan mengalami kesulitan, terutama dalam hal melibatkan "jaringan" atau multiplisitas organisasi, yaitu bagaimana organisasi berinteraksi satu sama lain, tidak hanya dalam bentuk dukungan dari DPRD. Dalam implementasinya kerjasama tersebut sebaiknya mengikuti pendekatan yang dianjurkan oleh Aldrich, terutama pendekatan kekuasaan dan ketergantungan sumber daya. Pendekatan ini berargumen bahwa interaksi organisasi adalah produk dari hubungan kekuasaan di mana organisasi-organisasi dapat membuat organisasi yang lebih lemah dan lebih tergantung untuk berinteraksi dengan mereka. Pada gilirannya, organisasi-organisasi yang tergantung pada organisasi-oragnisasi yang lebih kuat harus menjalankan strategi bekerjasama dengan organisasi yang kuat untuk mengamankan kepentingan mereka dan mempertahankan otonomi relatifnya atau mempertahankan ruang mereka untuk beroperasi. Dilihat dari perspektif Aldrich, kerjasama pengelolan mata air Umbulan tersebut melibatkan empat daerah yang akan memanfaatkan mata air tersebut, yaitu Kota Surabaya, Kabupaten Gresik, Kabupaten Sidoarjo, dan Kabupaten Pasuruan. Apalagi Kota Surabaya, Kabupaten Gresik, dan Kabupaten Sidoarjo yang posisinya lebih lemah dan membutuhkan sumber air tersebut, seharusnya membentuk lembaga kerjasama yang independen dan professional untuk bekerja secara aktif dan intensif. Kelemahan yang paling mendasar adalah pola kerjasama pengelolaan mata air Umbulan tidak memiliki payung politik yang kuat misalnya dalam bentuk Peraturan Daerah atau Peraturan Gubernur/Bupati/Walikota.

\section{SIMPULAN}

Dari uraian di atas, terlihat bahwa kerjasama pengelolaan mata Umbulan belum berjalan dengan optimal, walaupun produk hukum berupa MoU antara Pemerintah Provinsi Jawa Timur dengan Kabupaten Pasuruan telah ditandatangani, yang ditindaklanjuti dengan pembentukan Tim Kerjasama, dan Kelompok Kerja Pengelolaan Sumber Daya Air Umbulan. Namun, dalam proses pembuatan kebijakan, terutama pembentuk tim kerjasama, tidak melibatkan kalangan privat, masyarakat dan kalangan profesional.

Upaya-upaya yang dilakukan dalam mengimplementasikan kerjasama pengelolaan mata air Umbulan, yakni mencari investor dan melakukan negosiasi dengan pihak pemilik mata air Umbulan (Kabupaten Pasuruan) belum berhasil. Belum berhasilnya disebabkan oleh beberapa faktor, yaitu: 
(1) dalam proses maupun implementasi kebijakan tidak melibatkan tiga daerah lainnya yang akan memanfaatkan mata air, yaitu Kota Surabaya, Kabupaten Gresik, dan Kabupaten Sidoarjo; (2) belum ada payung politik yang memadai; dan (3) kurang pelibatan stakeholders, terutama kalangan privat dan masyarakat yang mempunyai kepentingan terhadap mata air Umbulan.

Oleh karena itu, disarankan agar Pemprov Jawa Timur membuat strategi kerjasama dalam pengelolaan mata air Umbulan dengan melibatkan Pemerintah Kabupaten Pasuruan, Kabupaten Sidoarjo, Kabupaten Gresik dan Kota Surabaya, dengan tahap-tahap sebagai berikut: (1). membuat payung hukum yang lebih jelas; (2) tim yang telah dibentuk pihak-pihak yang mengadakan kerjasama, baik Pemerintah Provinsi Jawa Timur maupun Pemerintah Kabupaten Pasuruan, Kabupaten Sidoarjo, Kabupaten Gresik dan Kota Surabaya perlu dirampingkan dengan memperhatikan kompetensinya dan keinginan untuk mau bekerja; (3) mengefektifkan tim dengan membuat jadwal pelaksanaan yang jelas; (4) membentuk lembaga/badan independen yang anggotanya dari kalangan birokrat dan profesional, di mana tanggungjawab manajemen dipegang oleh kaum profesional yang bertugas membuat mekanisme kerja, membuat profil Umbulan dan menawarkan kepada investor, sedangkan posisi birokrat sebagai dewan penasehat; dan (5) melakukan sosialisdasi tentang expected gain terhadap semua pihak yang terlibat dalam kerjasama tentang kepastian bahwa kerjasama akan lebih berhasil apabila melibatkan beberapa pihak dari pada dikelola sendiri.

\section{DAFTAR PUSTAKA}

Bryant, Carolin dan Louise G. White. 1987. "Manajemen Pembangunan Untuk Negara Berkembang”, L3PES, Jakarta.

Dunn, William N. 1992. "Public Policy Analysis: An Introduction", University of Pittsburgh, Prentice - Hall International, Inc..

Dunn, William N. 1995. "Analisa Kebijakan Publik", University of Pittsburgh, disunting oleh Muhajir Darwin, Penerbit Hanindita Graha Widya, Yogyakarta.

Meter, Van and Van Horn, 1975. "The Policy Implementation Process: A Conceptual Frame Work, Administration and Society.

Person, Wayne. 2005. "Public Policy: Pengantar Teori dan Praktik Analisis Kebijakan", Prenada Media, Jakarta.

Sosrodarsono, Suyono dan Kensaku Takeda. 1999. "Hidrologi Untuk Pengairan", Pradnya Paramita, Jakarta.

Undang-UndangNomor 32 Tahun 2004 tentang Pemerintahan Daerah.
Wahab, Solichin Abdul. 1997. "Analisis Kebijakan: Dari Formulasi Ke Implementasi Kebijakan Negara", Penerbit Bumi Aksara, Jakarta 